\title{
AKTUALISASI NILAI NILAI PANCASILA DAN KESADARAN BELA NEGARA ALUMNI SMKN 1 TEMANGGUNG ANGKATAN 43
}

\author{
Ani Sukawati \\ Politeknik Pembangunan Pertanian Yogykarta-Magelang Jurusan Pertanian \\ Anisukawati311@gmail.com
}

\begin{abstract}
ABSTRAK
Pancasila sebagai ideologi telah disepakati bersama sejak indonesia merdeka. Penerpan mengenai nilai nilai yang terkandung dalam pancasila serta kesadaran bela negara oleh para pemuda menjadi hal yang penting dan tidak bisa disepelekan. Dari hal tersebut, dapat diketahui bagaiman masa depan indonesia. Apakah masih eksis sebgai negara kesatuan atau malah berpotensi terpecah belah. Dalam penelitian yang dilakukan, tujuanya adalah mengetahui aktualisasi pengamalan pancasila dan bela negara oleh para pemuda alumni SMKN 1 Temnggung angkatan 43. Serta untuk mengetahui apakah terjadi singkronisai pemikiran mengenai pemahaman mereka pada nilai nilai baik pancasila dengan hal yang mereka lakukan dalam kehidupan sehari hari mereka. Penelitian dilakukan menggunakan metode deskripif kuantitatif dengan memberikan sejumlah pertanyaan kepada 30 orang responden. Responden adalah alumni SMKN 1 Temanggung angkatan 43 dari berbagai jurusan . Hasilnya, setiap pemuda sesungguhnya memiliki tekat dalam hati yang kuat untuk berbuat baik dan bersikap baik. Namun dalam kenyataanya, beberapa dari mereka masih hanya menjadikan pemikiran atau ide ide itu hanya ada dalam khayalan. Atau dalam kata lain, penerapan dalam kehidupan nyata masih kurang. Hal ini disebabkan oleh berbagai faktor baik faktor internal maupu faktor eksternal. Faktor internal yang muncul dari diri sendiri sesunggunya merupakan refleksi dan akibat dari pengamatan terus menerus pada lingkungan tempat tinggal. Oleh karenanya, faktor internal dan eksternal ini saling memengaruhi satu sama lain. Pendidikan karakter memiliki andil yang besar dalam menciptakan generasi muda yang baik dalam pemikiran dan dapat menjadikan pemikiran baik tadi menjadi kenyataan dibuktikan dengan pengamalan nilai-nilai pancasila dan bela negara dalam kehidupan sehari hari.
\end{abstract}

Kata kunci : Aktualisasi, Pancasila, Bela negara, Pemuda.

\begin{abstract}
Pancasila as an ideology has been mutually agreed upon since Indonesia's independence. The implementation of the values contained in Pancasila and the awareness of defending the country by the youth is important and cannot be underestimated. From this, it can be seen what the future of Indonesia is like. What its still exists as a unitary state or even has the potential to be divided. This research was conducted with the aim of knowing the actualization of the practice of Pancasila and state defense by youth alumni of SMKN 1 Temnggung class 43. As well as to find out whether there is synchronization of thoughts regarding their understanding of the good values of Pancasila with what they do in their daily lives. The research was conducted using quantitative descriptive methods by giving a number of questions to 30 respondents. The respondents were alumni of SMKN 1 Temanggung, class 43 from various departments. As a result, every youth actually has a strong determination in his heart to do good and be kind. But in reality, some people still only make those thoughts or ideas exist in delusion. Or in other words, the application in real life is still lacking. This is caused by various factors, both internal and external factors. Internal factors that arise from oneself are actually a reflection and a result of continuous observation of the environment in which they live. Therefore, these internal and external factors influence each other. Character education has a big share in creating young people who are good at thinking and can make these good thoughts a reality as evidenced by the practice of the values of Pancasila and defending the country in everyday life.
\end{abstract}

Keywords: Actualization, Pancasila, State Defense, Youth.

\section{PENDAHULUAN}

Pancasila adalah ideologi dan
pandangan hidup bangsa Indonesia.

Pancasila juga merupakan dasar dari setiap kegiatan pemerintahan. Keberadaanya harus dijadikan pedoman agar dapat 
terselenggaranya kehidupan bangsa yang aman, damai, dan sejahtera. Menurut Prof. Drs Notonagaro SH menyatakan pancasila sebagai dasar negara mempunyai kedudukan istimewa dalam hidup kenegaraan dan hukum bangsa indonesia (merupakan pokok kaidah negara yang fundamental).

Kemerdekaan bangsa Indonesia sudah berlangsung lebih dari 70 tahun. Setelah proklamasi dikumandangkan pada 17 Agustus 1945, setiap elemen masyarakat harus menjaga agar kemerdekaan bukan hanya menjadi pencapaian emas tanpa makna yang digembor gemborkan ke seluruh penjuru dunia. Oleh karenanya, kegiatan mengisi waktu demi waktu setelah kemerdekaan ini, seyogyanya digunakan sebaik mungkin demi terciptanya cita cita luhur para mendiri bangsa yang tertuang dalam Pembukaan Undang Undang Dasar Negara Republik Indonesia Tahun 1945 alinea ke-3 yaitu melindungi segenap bangsa indonesia dan seluruh tumpah darah indonesia, memajukan kesejahteraan umum, mencerdaskan kehidupan bangsa, dan ikut melaksanakan ketertiban dunia yang berdasarkan kepada perdamaian abadi dan keadilan sosial.

Menjaga dan mempertahankan indonesia adalah tugas dari seluruh elemen masyarakat tanpa kecuali. Bangsa indonesia harus bersatu padu dan menghindari perpecahan walau dengan keberagaman masyarakat yang majemuk. Perbedaan ras, suku, bahasa, dan agama adalah hal yang unik di Indonesia. Hal itu menjadi warna tersendiri yang menjadi bagian dari keindahan negeri ini. Salah satu hal yang menarik di Indonesia adalah pancasila. Pancasila bukan hanya gagasan biasa, namun adalah buah dari pemikiran cemerlang para pendiri bangsa.

Dewasa ini, arus globalisasi dan modernisasi semakin kuat dirasakan.
Pembaharuan mulai muncul dari segala bidang. Orang orang mulai merubah pola pikir dan gaya hidup mereka. Para pemuda, sebagai generasi penerus bangsa juga terlihat jelas ikut dalam arus globalisasi dan modernisasi ini. Dari segi ideologis politis, pemuda adalah penerus terdahulu dalam hal ini berusia antara 17-35 tahun ditetapkan sebagai diakuinya hak hak politik pemuda dalam kehidupan berbangsa dan bernegara sebagaimana dapat dilihat dari keikutserataan mereka dalam kegiatan pemilu pada usia 17 tahun (Saefulloh dkk). Sementara itu generasi muda atau biasa disebut kelompok muda dalam konteks kehidupan manusia, merupakan bagian dari masyarakat dengan usia dan fungsi yang strategis. Saat ini nilai nilai pancasila dalam diri bangsa mulai luntur seiring berjalanya waktu.

Terkikisnya nilai nilai pancasila di kalangan para pemuda saat ini adalah akibat dari pemahaman yang kurang mengenai nilai nilai pancasila. Informasi yang dapat diakses dengan cepat oleh siapapun dan kapanpun, jika tidak digunakan dengan baik juga dapat bedampak buruk bagi para pemuda. Para pemuda yang harusnya bersemangat tinggi, bersosialisasi dengan banyak orang, membangun kepercayaan diri dan mencari jati diri saat ini malah sibuk dengan gawai dan cenderung bermalas malasan.

Selain itu, bela negara juga merupakan hak dan kewajiban setiap warga negara termasuk pemuda. Hal itu tercantum dalam Undang Undang Dasar Negara Republik Indonesia Tahun 1945 Pasal 27 Ayat (3) dan Pasal 30 Ayat (1). Pasal 27 Ayat (3) dan Pasal 30 Ayat (1) mengisyaratkan bahwasanya usaha pembelaan negara merupakan hak dan kewajiban warga negara dengan tidak ada pengecualian. Namun kenyataan saat ini, kesadaran bela negara belum dapat 
dilaksanakan secara menyeluruh oleh para pemuda di indonesia. kekerasan antar pelajar, tawuran, penggunaan narkotika, bahkan terorisme kini mulai menjamah kaum muda. Rendahanya rasa nasionalisme para pemuda menimbulkan ketidakberdayaan pemuda, untuk ikut serta melindungi tanah air dan tumbah darah Indonesia, bersikap hedonis, konsumtif, dan pragmatis.

Tujuan ppenelitian ini adalah untuk mengetahui aktualisasi pengamalan pancasila dan bela negara di kalangan ppemuda alumni SMKN 1 Temnggung angkatan 43. Serta untuk mengetahui apakah terjadi singkronisai pikiran mengenai pemahaman mereka pada nilai nilai baik pancasila dengan hal yang mereka lakukan dalam kehidupan sehari hari mereka.

\section{METODE}

Menurut Kartini Kartono, metode penelitian adalah cara cara berfikir dan berbuat yang dipersiapkan dengan baik untuk mengadakan penelitian dan guna mencapai tujuan penelitian. Penelitian ini menggunakan metode deskriptif kuantitatif dengan pengamatan serangkaian peristiwa yang terjadi, pengamatan sejarah / atau masa lalu yang berdasarkan situasi dan kondisi saat ini serta menggunakan studi kepustakaan.

Penelitian dilaksanakan pada bulan Februari 2021 . Untuk data primer, penulis memberikan 25 butir petanyaan kepada 30 orang responden yaitu alumni SMKN 1 Temanggung angkatan 43 dari berbagai jurusan. Jawaban kemudian dihimpun untuk selanjutnya dilakukan analisis.

\section{HASIL DAN PEMBAHASAN}

Dalam kegiatan penelitian yang dilakukan, petanyaan yang diajukan kepada responden adalah sebagai berikut :
Tabel 1. Daftar pertanyaan pada responden

\begin{tabular}{|c|c|}
\hline No & \\
\hline 1. & $\begin{array}{l}\text { pakah anda memeluk salah satu } \\
\text { lantara enam agama resmi di } \\
\text { dsonesia? }\end{array}$ \\
\hline 2. & $\begin{array}{l}\text { Apakah anda selalu menjalankan } \\
\text { kegiatan peribadatan sesuai } \\
\text { agama yang dianut? }\end{array}$ \\
\hline 3. & $\begin{array}{l}\text { Apakah anda setuju bahwa } \\
\text { toleransi itu penting ? }\end{array}$ \\
\hline 4. & $\begin{array}{l}\text { Apakah anda menghargai teman } \\
\text { yang berbeda agama dengan } \\
\text { tidak mengejek baik verbal } \\
\text { maupun nonverbal? }\end{array}$ \\
\hline 5. & $\begin{array}{l}\text { inda kesopanan } \\
\text { ig ? }\end{array}$ \\
\hline 6. & $\begin{array}{l}\text { rsikap sopan dan } \\
?\end{array}$ \\
\hline 7. & $\begin{array}{l}\text { Apakah anda setuju bahwa } \\
\text { membantu orang adalah sustu hal } \\
\text { yang baik? }\end{array}$ \\
\hline 8. & $\begin{array}{l}\text { Apakah anda memberikan } \\
\text { donasi/doa/bantuan } \\
\text { korban bencana alam? }\end{array}$ \\
\hline 9. & $\begin{array}{l}\text { Apakah anda setuju bahwa rasis } \\
\text { u tidak baik? }\end{array}$ \\
\hline 10. & $\begin{array}{lccr}\text { Apakah } & \text { anda } & \text { mau } & \text { berteman } \\
\text { dengan orang } & \text { yang } & \text { berbeda } \\
\text { rasnya? } & & & \\
\end{array}$ \\
\hline 11. & $\begin{array}{l}\text { ah anda setuju bahwa cinta } \\
\text { air itu penting ? }\end{array}$ \\
\hline 12. & $\begin{array}{l}\text { Jika anda membeli barang, } \\
\text { apakah saat membelinya anda } \\
\text { juga mempertimbangkan } \\
\text { produsenya dari dalam negeri } \\
\text { atau bukan? }\end{array}$ \\
\hline 13. & $\begin{array}{l}\text { Apkah anda setuju } \\
\text { dengan musyawarah } \\
\text { mendapatkan jalan } \\
\text { terbaik dari suatu permaslahan? }\end{array}$ \\
\hline 14. & $\begin{array}{l}\text { Beranikah anda mengemukakan } \\
\text { pendapat saat musyawarah? }\end{array}$ \\
\hline 15. & $\begin{array}{l}\text { Apakah anda termasuk orang } \\
\text { yang kurang puas terhadap } \\
\text { pemerintah? }\end{array}$ \\
\hline
\end{tabular}




\begin{tabular}{|r|l|}
\hline 16. & $\begin{array}{l}\text { Apakah anda mau ikut serta } \\
\text { menjadi bagian dari pemerintag } \\
\text { dengan tujuan memperbaiki hal } \\
\text { yang dirasa buruk di pemerintah } \\
?\end{array}$ \\
\hline 17. & $\begin{array}{l}\text { Apakah menurut anda keadilan } \\
\text { itu penting? }\end{array}$ \\
\hline 18. & $\begin{array}{l}\text { Apakah jika orang terdekat anda } \\
\text { salah anda akan tetap membela ? }\end{array}$ \\
\hline 19. & $\begin{array}{l}\text { Apakah anda tau bahwa masih } \\
\text { ada ketimpangan sosial di } \\
\text { Indonesia? }\end{array}$ \\
\hline 20. & $\begin{array}{l}\text { Apakah anda mau menjadi } \\
\text { relawan pendidikan atau relawan } \\
\text { sosial di daerah tertinggal ? }\end{array}$ \\
\hline 21. & $\begin{array}{l}\text { Apakah anda akan marah jika } \\
\text { salah satu tarian daerah } \\
\text { Indonesia diakui negara lain ? }\end{array}$ \\
\hline 22. & $\begin{array}{l}\text { Apakah anda ikut melestarikan } \\
\text { budaya setempat? }\end{array}$ \\
\hline 23. & $\begin{array}{l}\text { Apakah anda berfikir bahwa } \\
\text { pancasila adalah ideologi terbaik } \\
\text { bagi bangsa Indonesia? }\end{array}$ \\
\hline 24. & $\begin{array}{l}\text { Apakah anda mau diminta } \\
\text { mengikuti wajib militer jika ada } \\
?\end{array}$ \\
\hline 25. & $\begin{array}{l}\text { Apakah anda } \\
\text { membanggakan } \\
\text { melalui prestasi akademik/non } \\
\text { akademik/ wirausaha ? }\end{array}$ \\
\hline
\end{tabular}

Dari berbagai pertanyaan yang diajukan oleh peneliti, pertanyaan nomor 1-4 adalah pertanyaan yang berkaitan dengan pengamalan pancasila sila pertama yaitu "Ketuhanan Yang Maha Esa". Pertanyaan nomor 5-8 berkaitan dengan pengamalan pancasila sila ke dua yaitu "Kemanusiaan yang Adil dan Beradab". Pertanyaan nomor 9-12 berkaitan dengan pengamalan pancasila sila ke tiga yaitu "Persatuan Indonesia". pertanyaan nomor 13-16 berkaitan dengan pengamalan pancasila sila ke empat yaitu "kerakyatan yang dipimpin oleh hikmah kebijaksanaan

dalam permusyawaratan/perwakilan". Pertanyaan nomor 17-20 berkaitan dengan pengamalan pancasila sila ke lima yaitu "Keadilan sosial bagi seluruh rakyat indonesia". pertanyaan nomor 21-25 berkaitan dengan bela negara yang dilakukan oleh pemuda.

\section{Sila Pertama Ketuhanan Yang Maha Esa}

Nilai pancasila sila pertama sering disebut sebagai nilai dasar dari empat sila lainya. Ketuhanan Yang Maha Esa memberi makna yang kuat bahwa Indonesia adalah negara yang mempercayai satu tuhan atau biasa disebut monotheisme. Di indonesia ada enam agama yang diakui secara resmi oleh pemerintah. diantaranya adalah Islam, Kristen, Katolik, Budha, Hindu, dan Konghucu. Setiap warga negara harus mencantumkan agamanya didalam Kartu Tanda Penduduk (KTP). Setiap warga negara juga bebas memilih agama mana yang dianut. Indonesia merupakan negara dengan penduduk beragama islam terbanyak di dunia. Dewasa ini, pendirian negara islam di indonesia beberapakali diindikasikan muncul di tengah tengah masyarakat. Organisasi organisasi terlarang menyasar para pemuda untuk ikut dalam kegiatan mereka. Hal ini sagat memprihatinkan.

Kebebebasan beragama dijamin oleh negara. Dalam UUD 1945 pasal 28 Ayat (1) setiap orang bebas memeluk agama dan beribadat menurut agamanya, ayat (2) setiap orang berhak atas meyakini kepercayaan, menyatakan pikiran dan sikap sesuai dengan hati nuraninya. Sedangkan dalam UUD 194 pasal 29 ayat (2) negara menjamin kemerdekaan tiap tiap penduduk dan memluk agamanya masing masing dan untuk beribadat menurut agamanya dan kepercayaanya itu.

Penerapan dari sila pertama pancasila ini adalah dengan menjalankan peribadatan sesuai agama yang dianut. Tak 
hanya itu, pemahaman konsep toleransi juga penting ditanamkan sejak dini. Bahwasanya hidup dalam keberagaman agama bukanlah hal yang buruk. Saling menghormati dan menghargai pemeluk agama lain bisa dilakukan dengan tidak memaksakan kehendak untuk menjadikan negara Indonesia sebagai negara berdasarkan agama saja. hal ini berlaku bagi seluruh masyarakat Indonesia tanpa terkecuali.

Dalam penelitian yang dilakukan, semua responden menyatakan bahwasanya mereka memeluk salah satu diantara enam agama resmi di Indonesia. 86.7\% responden menyatakan bahwa mereka selalu menjalankan kegiatan peribadatan sesuai agama yang mereka anut. Sedangkan 13.3\% sisanya menyatakan kadang-kadang menjalankan peribadatan sesuai agama yang dianut. Selanjutnya, kesemua responden menyatakan setuju bahwasanya toleransi itu penting. Namun dalam penerapanya, $6.7 \%$ responden menyatakan terkadang tidak menghargai teman yang berbeda agama dengan tidak mengejek baik secara verbal maupun non verbal. Hal ini menunjukan bahwa setiap responen memiliki pemikiran yang baik dibuktikan dengan kesemuanya beragama dan mengetahui bahwa toleransi itu penting. Namun dalam pelaksananya masih saja ada hal yang membuat pemikiran tadi hanya menjadi angan tanpa adanya tindakan nyata. Hal-hal tersebut bisa muncul karena faktor internal maupun eksternal. Pendidikan agama yang baik, serta penanaman sikap toleransi sejak dini penting dilakukan agar dimasa yang akan datang tidak timbul suatu perpecahan.

\section{Sila Kedua Kemanusiaan Yang Adil Dan Beradab}

Nilai kemanusiaan yang dihadirkan dalam sila kedua ini mencakup keadilan bagi setiap orang dan sikap perilaku sehari hari yang baik dan beradab. Keadilan memiliki makna meletakkan sesuatu pada tempatnya dengan porsi yang sesuai. Bahwasanya manusia memiliki derajat yang sama dan di dalam pemerintahanpun kesemuanya memiliki hak yang sama untuk berpartisipasi.

Penerapan nilai kemanusiaan yang adil dan beradab ini penting dikasanakan dengan harapan terciptanya kehidupan yang tentram, aman, damai tanpa adanya konflik antar golongan. Tindakan kekerasan juga dapat ditanggulangi jika nilai pancasila sila kedua ini dapat dilaksanakan dengan baik. Salah satu nilai moral yang harus dimiliki manusia adalah karakter sopan santun (Lickona,2009). Sopan santun merupakan tata karama dalam kehidupan sehari hari sebagai cermin kepribadian dan budi pekerti luhur (Zuriah \& Yustanti, 2007)

Dalam penelitian yang dilakukan, kesemua responden setuju bahwasanya kesopanan dan adab itu penting keberadaanya. Sayangnya $46.7 \%$ responden menyatakan bahwa mereka hanya kadangkadang saja bersikap sopan dan santun dalam kehidupan sehari hari. Tidak dipungkiri, arus globalisasi dan modernisasi menjadi hal yang memengaruhi pola pikir pemuda dalam hal ini. Padahal, kesopanan adalah hal penting yang mencerminkan jati diri bangsa Indonesia, berbeda dengan budaya barat yang cenderung individualis dan acuh terhadap orang lain. Selanjutnya, seluruh responden menyatakan setuju bahwa membantu orang lain yang terkena musibah tanpa mempertimbangkan suku, ras, dan agamanya adalah perbuatan yang baik. $90 \%$ menyatakan mereka memberikan donasi atau doa atau bantuan kepada korban bencana alam yang terjadi di Indonesia. Sedangkan, $10 \%$ menyatakan tidak memberikan donasi atau doa atau bantuan kepada korban bencana alam. Rasanya, sikap peduli dari pemuda kembali dipertanyakan disini. Memberikan empati 
tidak harus dengan memberikan sejumlah uang atau bantuan keapada korban bencana alam, namun juga bisa dengan memberikan doa bagi mereka. Dalam kenyataanya, masih saja ada pemuda yang enggan memberikan donasi atau doa atau bantuan kepada korban bencana alam di Indonesia .

Seperti halnya pada penerapan sila pertama, penerapan sila kedua ini juga mengindikasikan tidak singkronnya antara keinginan/ pemikiran dengan kenyataan. Para pemuda sudah memiliki pemikiran dan pemhaman yang baik mengenai apa yang harus dilakukan dan apa yang tidak baik untuk dilakukan. Namun dalam kenyataanya, masih saja ada hal yang membuat pemikiran baik tersebut hanya sekedar menjadi khayal bukan menjadi suatu yanng aktual.

\section{Sila ketiga Persatuan Indonesia}

Indonesia terdiri dari beragam suku dan budaya yang majemuk. Tersebar dari titik $0 \mathrm{~km}$ indonesia yaitu Sabang hingga ke ujung indonesia bagian timur yaitu Merauke. Menurut BPS tahun 2010, ada 1.340 suku bangsa di Indonesia. sementara itu, dilansir dari kemendikbud.go.id memverifikasi bahwa ada 652 bahasa daerah di indonesia. jumlah tersebut tidak termasuk dialeg dan subdialeg.

Komitmen kebangsaan untuk tetap menjaga eksistensi Negara Kesatuan Republik Indonesia menjadi hal yang penting keberadaanya. Saling peduli dan mendukung sesama warga negara perlu dilakukan. agar dapat tercipatanya kehidupan kebangsaan yang maju dan dapat berkembang dengan baik. Muara dari semua hal itu adalah terciptanya kesejahteraan sosial bagi seluruh rakyat indonesia.

Dalam penelitian yang dilakukan, seluruh reponden setuju bahwasanya rasis itu tidak baik. Dan 100\% responden juga menyatakan bahwa mereka menerima dan mau berteman dengan orang yang memiliki ras yang berbeda dengan dirinya. Hal ini dirasa baik dikarenakan kemajemukan Indonesia memang tidak dipungkiri memerlukan tempat tersendiri dalam perasaan setiap warganya untuk dapat menerima orang lain yang berbeda dengan dirinya. Kesemua responden juga menyatakan mereka menyetujui bahwa cinta tanah air itu penting. Cinta tanah air dapat dilakukan salah satunya dengan menggunakan atau membeli produk produk dalam negeri. Namun, dalam pertanyaan yang diberikan mengenai jika membeli barang, apakah mempertimbangkan produsen produk yang akan dibeli dari dalam negeri atau bukan, hanya $23.3 \%$ yang menyatakan iya. $60 \%$ menyatakan kadang kadang dan $16.7 \%$ lainnya menyatakan tidak mempertimbangkan barang yang dibeli adalah produk indonesia atau bukan. Padahal, mendukung produk dalam negeri adalah hal yang dapat memberikan dampak positif bagi para produsen dalam negeri. Tapi memang, beberapa produk dalam negeri memiliki kualitas yang tidak lebih baik daripada produk luar negeri. Kontinyuitas stok juga masih menjadi kendala bagi produk produk yang diusahakan oleh pengusaha kecil. Oleh karenanya, peran serta pemerintah untuk memajukan produk lokal sangat diharapkan. Pembenahan sistem regulasi dilapangan serta penekan terhadap impor produk diharapakan secara nyata dilakukan oleh pemerintah. Peran serta masyarakat termasuk didaamya pemuda dalam menciptakan inovasi-inovasi baru yang kreatif juga diharapkan agar produk produk dalam negeri dapat bersaing dengan produk luar negeri.

\section{Sila ke empat Kerakyata Ynag Dipimpin Hikmah Kebijaksanaan Dalam Permusyawaratan/ Perwakilan}


Semangat demokrasi sudah lama dikumandangkan. Setiap orang memiliki hak yang sama dalam pemerintahan. Dalam pasal 27 ayat (1) UUD 1945 menentukan bahwa "segala warga negara bersamaan kedudukanya didalam hukum dan pemerintahan dan wajib menjunjung hukum dan pemerintahan itu dengan tidak ada kecualinya." Kedaulatan tertinggi Negara Kesatuan Repubik Indonesia ada ditangan rakyat diwakilkan oleh para wakil rakyat yaitu DPR (Dewan Perwakilan Rakyat) dan DPD (Dewan Perwakilan Daerah) yang dipilih dalam pemilu (Pemilihan Umum).

Pada tanggal 1 Juni 1945 saat sidang BPUPKI , Ir. Soekarno menyampaikan pidato yang isinya “... Dasar itu ialah dasar mufakat, dasar perwakilan, dasar permusyawaratan. Negara indonesia bukan merupakan negara untuk satu orang, bukan negara untuk satu golongan, walaupun golongan kaya. Tapi kita semua mendirikan negara satu untuk semua, satu buat semua, saya yakin bahwa syarat yang mutlak untuk kuatnya negara indonesia ialah permusyawaratan perwakilan". Menjadikan musyawarah dari perwakilan perwakilan setiap daerah dalam mengambil keputusan bersama dalah hal yang harus dilakukan. agar tidak terjadi kesalah fahaman maupun pemikiran negratif atau juga pengendalian oleh tangan-tangan otoriter.

Dari pertanyaan yang diberikan kepada 30 orang responden, kesemuanya menyatakan bahwa dengan musyawarah mufakat, bisa mendapatkan jalan keluar terbaik dari suatu permaslahan. Namun 30\% responden menyatakan bahwa mereka tidak yakin akan berani mengemukakan pendapat mereka dalam forum musyawarah. Hal ini cukup memperihatinkan. Indonesia membutuhakan pemuda pemuda yang mampu berfikir kritis dan berani menyampaikan pemikiran mereka. Kontrol terhadap pemerintah dan berbagai kebijakan bisa dilakukan oleh para pemuda dengan speak up atau menyatakan keluhan dan masukan pada pihak pihak terkait jika ada kebijakan yang kurang sesuai dengan kehidupan di masyarakat. Jangan sampai pemuda yang jumlahnya besar, hanya menjadi "tukang ikut" yang tidak kritis dan cenderung acuh pada permaslahan yang terjadi dalam kehidupan berbangsa dan bernegara. Tentunya dengan tetap mempertimbangkan privasi dari setiap orang, jangan sampai juga tindakan peduli disalah artikan dengan terlalu ikut campur masalah orang lain. Pembiasaan diri untuk berani menyampaikan pendapat dalam perlu dilakukan sejak dini. Melatih mental dengan berbicara di depan umum, megikuti kompetisi, atau berorganisasi bisa menjadi cara yang efektif untuk melatih kepercayaan diri. Selanjutnya, $76.7 \%$ responden menyatakan ketidakpuasan mereka terhadap pemerintah. $23.3 \%$ lainya menyatakan puas dengan pemerintahan yang berjalan saat ini. $66.7 \%$ responden menyatakan mau jika diminta ikut serta menjadi bagian di pemerintahan dengan tujuan memperbaiki hal yang dirasa buruk di pemerintah. sebagian lainya yaitu $33.3 \%$ menyatakan tidak ingin ikut campur dalam kegiatan pemerintahan. Pemerintahan menjadi hal yang menarik sekaligus kompleks. Maka dari itu wajar jika sebagian ingin berpartisipasi di dalamnya dan sebagian lainya menyaktakan keengganan untuk berpartisipasi disana.

\section{Sila Kelima Keadilan Sosial Bagi Seluruh Rakyat Indonesia}

Setiap warganegara dipandang sama oleh hukum dan negara. Pernyataan sepeti "tidak pandang bulu" adalah ungkapan yang harus direalisasikan dan menjadikanya bukan hanya isapan jempol belaka. Penegakan hukum dan asas keadilan sosial dapat berupa penegakan hukum, pengentasan dari kemiskinan dan 
kebodohan, serta usaha untuk menciptakan kesejahteraan umum masyarakat. Menghindari segala bentuk ancaman dan intimidasi merupakan hal yang harus dilakukan oleh pemrintah dan elemen elemen di pemerintahan. Tegaknya keadilan membuat bangsa Indonesia lebih mudah untuk bersatu dan memperjuangkan kesejahteraan umum. Nilai keadilan sosial bagi seluruh rakyat indonesia memilki makna tersendiri yaitu sebagai dasar sekaligus tujuan tercapainya masyarakat indoensia yang adil dan makmur secara lahiriah maupun batiniah.

Dalam penelitian yang dilakukan, responden setuju bahwasanya keadilan bagi setiap manusia itu penting. Namun, $13.3 \%$ responden ketika ditanya apakah akan membela jika teman terdekat salah menyatakan ya, akan tetap membela. Hal ini tentunya bertentangan dengan pernyataan sebelumnya bahwa semua responden menyatakan persetujuanya dalam hal keadilan itu penting. Selanjutanya, $86.7 \%$ mengamini bahwasanya di indonesia masih terjadi ketimpangan sosial. Dalam pertanyaan lain, $80 \%$ responden menyatakan mau menjadi relawan pendidikan atau relawan sosial di daerah tertinggal. Sedangkan sisanya menyatkan keberatan dengan berbagai pertimbangan.

\section{Kesadaran Bela Negara}

Kesadaran bela negara oleh para pemuda mengalami kemunduran akhir-akhir ini. Kemunduran ini dapat dilihat dari aspek kecintaan terhadap tanah air, rela berkorban demi bangsa dan negara, keyakinan pada ideologi pancasila dan kesadaran berbangsa dan bernegara yang kian menurun. Kemunduran ini disebabkan oleh berbagai faktor dinataranya kuatnya arus globalisasi dan modernisasi dimana kemudahan mengakses informasi semakin luas dan tak terbatas. Pengoptimalan pemahaman pemuda sejak dini mengenai bela negara juga dirasa kurang. Trauma masa lalu pada tragedi 1998 juga menjadi hal lain yang membuat bela negara terkesan ekstrem dan menakutkan. Padahal, kegiatan bela negra dapat dilakukan para pemuda pemudi secara senerhana. Apalagi di era saat ini, kegiatan bela negra yang berhubungan dengan fisik seperti kemiliteran juga tidak seintensif zaman perjuangan dulu. Pancasila, nasionalisme, patriotisme, dan wawasan kebangsaan penting ditanamnkan dalam diri setiap pemuda indonesia. apalagi para pemuda adalah tulang punggung serta harapan di masa depan bangsa indonesia.

Aktivasi kesadaran bela negara oleh para pemuda harus ditanamkan sejak dini mulai dari lingkungan keluarga, sekolah, dan masyarakat. Penguatan karakter para pemuda penting keberadaanya untuk mengatasi berbagai ancaman, tantangan, hambatan dan ganguan yang berpotensi mengancam Negara Kesatuan Republik Indonesia. menurut Suryato Suryokusumo, dkk "kekuatan rakyat adalah sumber dari kekuatan negara, kekuatan pertahanan nonmilite dibangun dari potensi kekuatan sosial dan politik yang terkandung pada masyarakat.

Dalam penelitian yang dilakukan, seluruh responden berpendapat bahwa mereka akan marah saat mengetahui tarian daerah di Indonesia diakui negra lain, namun $10 \%$ diantara responden menyatakan mereka tidak ikut melestarikan budaya di tempat mereka tinggal. Cukup ironis memang jika mereka mengharapkan budaya Indonesia tetap menjadi milik indonesia sementara melestarikanya saja adalah hal yang tidak dilakukan. Selanjutnya, 96.7\% berfikir bahwa pancasila adalah ideologi terbaik bagi bangsa indonesia. sementara sisanya menyatakan tidak. Hal ini cukup memprihatinkan. Hal ini juga mengindikasikan kurangnya rasa cinta tanah 
air dan bela negara dari seluruh responden. Walau jumlahnya kecil, yaitu $0.3 \%$ hal tersebut tidak dapat disepelekan. Karena sebagaimana kita tahu suatu hal besar dimulai sdari hal kecil. Perlunya penguatan ideologi semakin jelas adanya. Peran pemerintah melalui pendidikan dasar, menengah, hingga perguruan tinggi perlu terus digalakkan. Demi menjaga keutuhan Negara Kesatuan Republik Indonesia. Sebanyak $80 \%$ Responden menyatakan setuju dan mau ikut dalam kegiatan wajib militer jika ada. Sebgian lain yaitu $20 \%$ menyatakan keberatanya. Yang terakhir, 97.3\% responden menyatakan mereka berusaha membanggakan indonesia melalui prestasi akademik atau non akademik atau wirausaha. Sementara sisanya yaitu $0.3 \%$ menyatakan tidak.

\section{KESIMPULAN}

Aktualisasi nilai nilai pancasila dan bela nega oleh para pemuda adalah hal yang penting, mengingat para pemuda adalah harapan masa depan bangsa dan negraa. Dari penelitian yang dilakukan, dapat ditarik kesimpulan bahwa setiap pemuda sesungguhnya memiliki tekat dalam hati yang kuat untuk berbuat baik dan bersikap baik. Namun dalam kenyataanya, bebrpa orang masih hanya menjadikan pemikiran atau ide ide itu hanya ada dalam khayalan. Atau dalam kata lain, penerapan dalam kehidupan nyata masih kurang. Hal ini disebabkan oleh berbagai faktor baik faktor internal maupu faktor eksternal. Faktor internal yang muncul dari diri sendiri sesunggunya merupakan refleksi dan akibat dari pengamatan terus menerus pada lingkungan tempat tinggal. Oleh karenanya, faktor internal dan eksternal ini saling memengaruhi satu sama lain. Pendidikan karakter memiliki andil yang besar dalam menciptakan generasi muda yang baik dalam pemikiran dan dapat menjadikan pemikiran baik tadi menjadi kenyataan dibuktikan dengan pengamalan niali nilai pancasila dan bela negara dalam kehidupan sehari hari.

\section{DAFTAR PUSTAKA}

Kartono, Kartini. (2002) Psikologi Umum. Sinar Baru Algeis Indonesia: Bandung

Kemendikbud. (2018). "Badan Bahasa Petakan 652 Bahasa Daerah di indonesia". diakses

Lickona, T. (2009). Educating For Character "How Our schools Can Teach Respect and Responsibility". Bantam

Notonagoro. (1967). Beberapa Hal Mengenai Falsafah Pantjasila. Pantjuran tujuh: Jakarta

Octavian, wendy. (2018). "Urgensi dan mengimplementasikan nilai nilai pancasila dalam kehidupan sehari hari bagi sebuah bangsa". jurnal bineka tunggal ika Vol 5 (2)

Suryakusuma, Suryanto, dkk. (2016). Bunga Rampai Konsep Sistem Pertahan Non Militer. Yayasan pustaka obor indonesia: Jakarta

Saefulloh, dkk. (2014). Modul 1 "Generasi dan Generasi Muda". PKNI4312 : perpustakaan UT diakses melalui pustaka.ut.ac.id pada 7 februari 2021

Syaputra dan Na'im. (2010). Kwarganegaraan Suku Bangsa Agama dan Bahasa Sehari hari Penduduk indonesia. Badan Pusat Statistik: jakarta-Indonesia

Undang-undang Dasar Negara Repubik indonesia 1945, Penjelasan umum.

Undang-undang Dasar Negara Repubik indonesia 1945, Batang tubuh.

Zuriah, N \& Yustanti, F. (2007). Pendidikan moral dan budi pekerti dalam prespektif perubahan: menggagas platform pendidikan budi pekerti secara kontekstual dan futuristik. Bumi aksara

\section{UCAPAN TERIMAKSIH}

Puji syukur saya ucapkan atas selesainya penulisan tulisan ini. Terimakasih kepada pihak 
pihak yang telah membantu dan memberikan dukungan baik materil maupun immateril. Terimaksih juga saya sampaikan pada para penulis handal yang karyanya saya jadikan referensi. Semoga saya bisa menjai seperti orang orang hebat tadi. Besar harapan saya tulisan ini dapat diterima dan memberi manfaat bagi siapaun yang membaca.

\section{TENTANG PENULIS}

$\begin{array}{ll}\text { Nama } & : \text { Ani Sukawati } \\ \text { TTL } & : \text { Temanggung, 23 Desember } \\ & 2000\end{array}$

Pekerjaan : Mahasiswa

Asal institusi : Politenik Pembangunan

Pertanian Yogyakarta

Magelang 